1 Title: Reflectance: current state of research and future directions for archaeological

2 charcoal: results from a pilot study on Irish Bronze Age cremation charcoals

4 Author names and affiliations

5 Dr Robyn Veal, McDonald Institute for Archaeological Research,

6 University of Cambridge \& Department of Archaeology, University of Sydney

7 Dr Lorna O'Donnell, University College Dublin

8 Dr Laura McParland, Royal Holloway, University of London

10 Corresponding author: Dr Robyn Veal (rjv33@cam.ac.uk)

11 Present/permanent address

12 McDonald Institute for Archaeological Research

13 University of Cambridge

14 Downing St

15 Cambridge, CB2 3ER, UK

\title{
17 Highlights
}

18 - This study is a first attempt to use the reflectance method to measure absolute

19 burn temperatures from charcoal of archaeological cremation burials.

- Reflectance as a method for estimating charcoal burn temperature has been under investigation for some time. To date studies have used modern pre-charred wood samples (formed under a variety of conditions) to establish basic performance parameters and calibration curves to apply to charcoals recovered from both archaeological and modern contexts.

- The method shows promise in its application to archaeologically recovered charred materials, especially wood, although to date, only a small number of studies have been completed.

- Reflectance results of the charcoal did not demonstrate the range of expected temperatures associated with cremation (ca. $650^{\circ} \mathrm{C}$ to as much as $1000^{\circ} \mathrm{C}$ ). A variety of explanations are considered. 
- In particular, proof of this method's utility in archaeology will require better rationalisation of the calibration curves used to date as these currently represent a variability of typically $100-150^{\circ} \mathrm{C}$ (and up to as high as $180^{\circ} \mathrm{C}$ ) for any one reflectance value

- Un-sieved soil samples should be collected routinely for this method to gather the smallest charcoal fractions

\section{Keywords}

39 Reflectance, charcoal absolute burn temperature, reflectance calibration curve, cremation

\section{Suggested reviewers}

42 1. Prof Dr Thomas Ludeman, University of Frieburg, archaeological and geological

43 charcoal expert. Recent co-organiser of the last international charcoal conference (2015).

45 Fakultät für Biologie/Abt. Geobotanik

46 Schänzlestr. 1

47 D-79104 Freiburg

48 Germany

49

50 http://www.geobotanik.uni-freiburg.de/Team-Ordner/tludemann

51 thomas.ludemann@biologie.uni-freiburg.de

53 2. Prof Andrew Scott, Royal Holloway, University of London, (UK) Emeritus geologist,

54 charcoal expert, esp in taphonomy, early publisher on reflectance

56 Department of Earth Sciences

57 Royal Holloway, University of London

58 Egham, Surrey,

59 TW20 0EX, UK

60

61 https://pure.royalholloway.ac.uk/portal/en/persons/andrew-scott 
$63 \quad$ A.Scott@,rhukl.ac.uk

65 3. Dr Freek Braadbaart, Wiskunde en Natuurwetenschappen, Instituut Biologie Leiden, 66 IBL/Plantencelfysiologie (Netherlands). Senior geological researcher; early and current

67 tester of the reflectance method on modern charcoals, and on geological charcoal

68 taphonomy.

70 Faculteit Archeologie, Material Culture Studies

71 Van Steenis gebouw

72 Einsteinweg 2

732333 CC Leiden

74 Room number $\mathrm{C} 126$

75

76 http://archaeology.leiden.edu/organisation/staff/braadbaartf.html\#contact

77 f.braadbaart@arch.leidenuniv.nl

79 4. Dr Ingelise Stuijts, Trinity College, Dublin, Irish Environmental History Network.

80 Long term charcoal expert in Ireland, and Europe: designed and implemented wood and

81 charcoal database (WODAN). Environmental archaeologist.

82 The Discovery Programme

8363 Merrion Square

84 Dublin

85 D2

86 Ireland

87

88 https://www.tcd.ie/trinitylongroomhub/iehn/profiles/stuijtsi.php

89 ingelise@discoveryprogramme.ie

90

91 5. Dr Jacqui McKinley, acknowledged senior UK cremation expert, osteoarchaeologist,

92 currently Wessex Archaeology,

93 Wessex Archaeology

94 Port Way House 
95 Old Sarum Park

96 SP4 6EB

97

98 http://www.wessexarch.co.uk/people/jacqueline-mckinley

99 j.mckinley@wessexarch.co.uk

100

101 Illustrations

102

103 Figures

104 Figure 1: Calibration graph of reflectance vs burn temperature

105

106 Figure 2: Map of site locations

108 Figure 3: Cremation pits and possible pyre pits, looking southwest. (Doody, 2008, p. 117)

110 Figure 4: Graph of comparison of calibration curves of McParland and Braadbart et al.

112 Figure 5: Graph of Hudspith calibration curve

\section{Tables}

115 Table 1: Context types, characteristics, and reflectance results of charcoals tested

120 Table 3: Variations in reflectance readings from six different studies, from McParland 121 (2010, ch 10).

122 The maximum difference of $1.81\left(\right.$ at $500{ }^{\circ} \mathrm{C}$ ) represents a potential variation of up to 180

$123{ }^{\circ} \mathrm{C}\left(\right.$ i.e. $\left.+/-90^{\circ} \mathrm{C}\right)$. This is the most extreme variation, and most fall within a range

124 representing a variation of ca. $100{ }^{\circ} \mathrm{C}\left(\right.$ i.e. $\left.+/-50{ }^{\circ} \mathrm{C}\right)$.

\section{Abstract}


cremations, which included calcined bone. As calcination of bone commences at $650^{\circ} \mathrm{C}$,

132 it was expected that the charcoals would reflect at least this temperature. This was not

133 the case for taxonomically identified charcoals $>2 \mathrm{~mm}$, nor for micro-charcoals of c.

$134250 \mu \mathrm{m}$, although measured temperatures rose slightly with decreasing fraction size of

135 charcoal remains. Depositional practice, combustion completeness and taphonomic

136 influences may have all played a part in this result, and these will need careful

137 consideration in different archaeological circumstances. However, the greatest challenge

138 for reflectance of archaeological materials lies in obtaining full agreement on the

139 production and use of reflectance calibration curves. Current calibration curves differ substantially, by $100-150^{\circ} \mathrm{C}\left(+/-50-75^{\circ} \mathrm{C}\right)$ and in one instance up to as much as $180^{\circ} \mathrm{C}$ $\left(+/-90^{\circ} \mathrm{C}\right)$. Without better agreement on calibration, the method's ultimate usefulness in archaeological research will be limited. At the level of refinement currently possible, it will still be useful for determining very high or very low temperature processes, and possibly the difference between charcoal fuel and raw wood fuel fires. The latter has distinct implications for estimating ancient forest wood consumption, since more wood is consumed in processes employing charcoal fuel. Proving the utility of reflectance for archaeological purposes may also require modification of normal practice for archaeological field collection of charcoal, to include collection and laboratory processing of un-sieved soil samples.

154 In the last forty years, the systematic study of archaeological charcoal has greatly

155 increased our knowledge of past environments as well as socio-economic activity relating 156 to fuel collection and consumption (Asouti and Austin, 2005; Chabal, 1992; Chabal et al., 157 1999, Dufraisse, 2006, Théry-Parisot et al., 2010, 143). In the laboratory, charcoal 158 analysis has been substantially limited to taxonomic identification, and more recently, 159 estimation of cropping indicators by examination of annual tree ring patterns, see for 160 example: Ludemann (2006), Veal (2012), Marguerie and Hunot (2007) . More recently, 161 attempts to further characterise modern charred materials in terms of their chemical and 162 physical characteristics have been made in experimental procedures designed to assist 163 archaeologists in their interpretation of ancient charred remains (Braadbaart et al., 2009;

164 Braadbaart et al., 2012; Braadbaart et al., 2016; Chrzavzez et al., 2011; Chrzavzez et al., 165 2014, Lancelotti et al., 2010).

167 Reflectance testing has been attested as a useful tool for demonstrating approximate burn 168 temperatures of modern, and some archaeological charcoal (Braadbaart and Poole, 2008; 
169 McParland et al. 2009a,b; McParland et al., 2010; Scott and Glasspool, 2005). A more

170 detailed explanation is provided in the supplementary material. (LINK HERE to

171 Supplementary material 1) McParland et al. (2010) have in particular, demonstrated the

172 almost linear relationship of reflectance of specially prepared samples of charcoal across

173 a range of wood species, temperatures, and charring times (as opposed to earlier work

174 which concentrated on one or two species, and sometimes limited charring times).

175 Extensive testing of the reflectance method over a range of archaeological depositional

176 types however has not yet been carried out. In this study, charcoals of a range of size

177 fractions from cremation burials were evaluated, since the expected temperature for

178 successful human cremation is inferred to reach $c a .650^{\circ} \mathrm{C}$ as a minimum (if calcined

179 bone is observed (Wahl, 1982:27.)). One domestic pit fill and two hearth contexts were

180 also evaluated as a comparison.

\section{$182 \quad 2 \quad$ Background}

$1832.1 \quad$ Reflectance of modern charcoals

184 Wood charcoal is formed through the heating of wood in the absence of oxygen, and can

185 be formed intentionally (in the manufacture of charcoal fuel), or as a by-product of wood-

186 fire burning. Soil examined from archaeological sites normally contains a mixture of

187 charcoal (incomplete burning of raw wood, or 're-burning' of charcoal fuel) as well as

188 ash (the remains of wood burned to completion in the presence of oxygen).

189 Morphological, physical and chemical properties of charcoal can differ depending on two

190 groups of variables associated with the heating process. The first group consists of heat

191 related variables, which include temperature, time of exposure and heating rate $\left({ }^{\circ} \mathrm{C} / \mathrm{min}\right)$.

192 The second group consists of wood property variables, which include taxon, size, thermal

193 conductivity and other variables that can change during the charcoalification process

194 itself, see for example: Braadbaart et al. (2007), Braadbaart and Poole (2008), and Asouti

195 (2007).

197 The connection between increasing temperature formation and increasing mean random

198 reflectance value (studied in polished blocks under oil) is relatively well established

199 (Braadbart and Poole, 2008; McParland et al., 2007; Scott and Glasspool, 2005). The 
200 reflectance (\%Ro) of charcoalified organic material provides information regarding the

201 absolute temperature to which the material in question has been exposed. This reflectance

202 is quantified and measured by comparison with the reflectance of known standards,

203 achieved through experimental work. The most comprehensive work on reflectance of

204 modern woods (McParland et al., 2009a) measured temperatures of modern wood

205 samples burned under a variety of controlled circumstances. Mean reflectance

206 measurements carried out on different species (Quercus, Corylus, Acer, Fraxinus, Betula,

207 Pinus, Erica, Calluna and Ulex) corresponded closely to the original temperatures at

208 which the modern charcoal was produced. This choice of woods is particularly pertinent

209 to ancient fuel studies as these taxa are very commonly observed in archaeological

210 assemblages. This method discriminated changes in reflectance levels at intervals of 50

$211{ }^{\circ} \mathrm{C}$ ranging from $300{ }^{\circ} \mathrm{C}$ to $1100{ }^{\circ} \mathrm{C}$. It proved (as did earlier studies) that a near linear

212 relationship exists between charcoal burn temperature, and average reflectance

213 measurements, regardless of time of heat exposure and at a variety of temperatures

214 (McParland et al., 2009a, 2010) (figure 1). Reviewing published calibration curves

215 shows that while the linear trend is always demonstrated, for any individual reflectance

216 measurement, agreement among the curves as to the associated temperature can vary by

217 as much as $100-180{ }^{\circ} \mathrm{C}$ (Section 5.1).

220 Fig 1 Calibration graph of reflectance vs burn temperature developed from charring of 221 modern oak wood under a variety of temperatures and times (modified from McParland 222 2010)

224 Experimental work on modern charcoals produced under laboratory conditions, provides 225 the backdrop for the present study, with the reflectance curve for Quercus developed by 226 McParland (2010) (also discussed in McParland et al. (2009a)), acting as the calibration 227 curve. If reflectance is to be of use in an archaeological setting, then we must exclude the 228 possibility that taphonomic processes undergone by archaeological charcoal will dull or 229 obliterate the reflectance signal of the charcoal remains and/or recognise when such 230 limitations may be present. If this concern can be allayed, then the technique may help 
231 establish actual burn temperatures under different technological conditions (for example,

232 metal smelting, ceramics and glass production), and thus improvements in technology (as

233 represented by higher heat processes). It should also be possible to discriminate between

234 charcoal and raw fuel fires.

$2362.2 \quad$ Irish Bronze Age Cremation

237 During the Bronze Age in Ireland, cremation was the predominant rite of treatment for

238 human remains (Lynch and O'Donnell, 2007, 105). The most likely form of the structure

239 may have been similar to that more visibly attested in later historic periods, for example

240 on coins from the Roman period (Toynbee, 1971, 32), and those pyres used even today

241 on the Ganges in the Hindu rite of cremation. Pyres are typically built by alternating and

242 increasingly smaller levels of logs built in a roughly pyramidic shape. The cremation

243 process would have been challenging in prehistory, depending as it does on time,

244 temperature and oxygen (Mc Kinley, 2000, 404).

246 The maximum temperature achievable in the combustion process will be affected by the

247 size, shape and quality (i.e. calorific potential) of the fuel; the structure of the pyre, (or

248 hearth or kiln); the body weight and fat content, ambient weather conditions, and the

249 supply of oxygen. A rough (but imperfect) proxy for calorific potential of a wood is its

250 specific gravity (a measure of relative density at a particular moisture content (Veal 2012,

251 33-34). In general, denser woods such as Quercus and Fraxinus produce a longer-lasting

252 source of heat than less dense woods such as Salix, Populus and Alnus (Gale 2003, 36).

253 In the study area Quercus appears to have been selected for cremation pyres during the

254 Bronze Age, possibly because of its high calorific potential (O'Donnell 2011; 2016).

256 Heat is not a fixed value for any one wood type since it will vary with moisture

257 conditions, size and shape of logs burnt, and other ambient factors in combustion (Lyons

258 et al., 1985). We speak of calorific potential in any fire process, as the actual calorific

259 return achieved will depend on the amount of heat value transferred to the object of

260 combustion. In open pyre cremation, a large amount of heat is lost to the atmosphere.

261 After cremation has completed, Irish research has shown that a sub-sample of bone, 
262 charcoal or a mixture of the two was taken from the funeral pyre and buried, within urns

263 in grave pits, or directly into grave pits (Lynch and O'Donnell, 2007). Charcoal from this

264 study is derived both from pyres and from cremation graves. Taphonomic processes

265 differ between the two contexts, for example in the pyres, wood would have burnt in situ,

266 suggesting that samples could be taken from the centre and outskirts of the pyre. This

267 may result in differing reflecance values, charcoal at the periphery of the pyre may have

268 burnt at lower temperatures than the centre. In any single cremation event, however,

269 bone and wood from a cremation pyre may have origins from anywhere in the fire, from

270 the centre, to the periphery and have been exposed to varying fire temperatures. As

271 burning progresses, fuel, both burnt and unburnt, can potentially move around in the fire

272 due to a range of agents, for example, differing temperature patches in the fire will be

273 present due to the varying flammability of materials present; oils or perfumes thrown

274 onto the fire will momnentarily increase temperature, and once temperature reaches body

275 fat ignition point, burning will progress more quickly. (LINK TO Supplementary

276 material 2). Fatter body parts (and their nearby fuel) may be more likley to burn and drop

277 through the pyre first. Observation of remains from some urns suggests a range of sizes

278 of charcoal are present at deposition. Upon excavation from urns or pits, the origins of

279 the recovered charcoal (in terms of its position in the cremation pyre) cannot be

280 determined, nor may its time spent in the pyre be estimated (McKinley 2008, 167-68).

281 While not the case at this study site, sometimes bones are found arranged vertically in

282 anatomic order within urns, however even in these (rare) cases, it is unlikely the charcoal

283 is also so organized. This would be exteremely difficult to carry out, but also, due to

284 charcoal's lightness and fragility, settlement will continue as the urn is being filled,

285 carried and potentially even after deposition. McKinley (2008) also notes that in her

286 experiments, roughly $700-900 \mathrm{kgs}$ of wood are required and the main process of

287 combustion occurs in about 2-3 hours, with the pyre being left overnight to cool. Even

288 after 8 hours, some of the body may still remain unburnt.

$290 \quad 2.3 \quad$ Archaeological background

291 Templenoe, Co. Tipperary, Ireland is the largest Bronze Age flat cemetery excavated in

292 Ireland (figure 2) where the remains of 89 grave pits, 57 of which contained cremated 
293 bone were excavated. Charcoal results from six graves and one potential pyre are

294 presented here (figure 3). Four possible pyre ventilation pits were also identified in

295 association with the burials. In situ burning was not evident, but they are classified as

296 potential pyres due to their location in the site and their larger dimensions than the grave

297 pits. Other domestic features, potentially unrelated to the cemetery include pits and

298 postholes, indicative of settlement activity. The cemetery was in use from the Early to the

299 Middle Bronze Age (dated by AMS radiocarbon determinations) (Mc Quade et al 2009,

$300 \quad 130-133)$.

301

302 Fig 2 Map of location

303

304 Fig 3 Cremation pits and possible pyre pits, looking southwest. (Doody 2008, p. 117)

306 Charcoal was analysed mainly from the grave and potential pyre pits, of which seven

307 samples are included in the present study. Seven native Irish wood species were

308 identified, dominated by Quercus (deciduous only, there being no evergreen Quercus in

309 Ireland), and Maloideae. Nomenclature follows Stace (1997). The other taxa present

310 were Fraxinus, Corylus avellana, Ulmus, Prunus avium/padus and Alnus.

312 Human skeletal remains were identified from 31 pit features from Templenoe. The

313 majority of the bone deposits within the cemetery contained less than $10 \mathrm{~g}$ of cremated

314 bone, with an overall range of between only $0.08 \mathrm{~g}$ and $697 \mathrm{~g}$, suggesting that token

315 deposits of bone only were buried, based on the average weight of a cremated adult

316 individual (Mc Kinley 1993). Four non-adults and 20 adults were present while one male

317 and one female were identified (Geber 2009, 213-215). Modern studies have shown that

318 temperatures ranging from 650 to $\geq 800^{\circ} \mathrm{C}$ are required to successfully cremate human

319 bone (i.e. until the bones are whitish to white in colour) (Wahl 1982, 27). In

320 archaeological samples however, the reliance upon colour as an indicator of exposure

321 temperature essentially an imprecise criterion both because of individual differences in

322 the ability to perceive fine colour distinctions and because burnt bones may change

323 colour if they are buried (Shipman et al 1984). A variety of colours are often observable 
324 in the remaining bones, and a complex interaction of many factors can influence colour,

325 and thus it cannot always be a reliable indicator of temperature (Devlin and Herrmann

326 2008). Some scholars have even noted that cremation may have occurred in a lower

327 temperature range in pre-history, from about $500-600{ }^{\circ} \mathrm{C}$ (Barber 1990; van Andringa et

328 al. 2013, Vol 1:8-9). Ignition starts from about $350^{\circ} \mathrm{C}$, with sufficient oxygen and

329 flammable material. In the process of cremation, temperatures of up to $1000^{\circ} \mathrm{C}$ can be

330 reached. Starter materials may have included brushwood, oils, perfumes, and of course,

331 textiles. These would all burn to completion and thus may be lost to the archaeological

332 record.

333

334 The people at Templenoe were good at cremating their dead. Taking various caveats into

335 account (Devlin and Hermann 2008), the grey-white colour of the majority of the

336 collected bone fragments in the samples indicates successful cremation. The bones

337 exhibit the fourth and fifth category of degree of burning, according to Wahl $(1982,21)$,

338 and Geber (2008), suggesting burning temperatures of $650-800{ }^{\circ} \mathrm{C}$. This corresponds

339 most closely with burn colour codes 5 and 6 as described by Steiner and Kuhn (1995).

340 Therefore, the samples should provide a useful control with which to compare the

341 burning temperatures as measured through reflectance. As a further comparison,

342 reflectance values were also measured from charcoal from one domestic pit at Templenoe

343 and from charcoal from two nearby Bronze Age domestic hearths, at Lissava and

344 Ballylegan (figure 2) (Mc Quade et al 2009).

\section{$346 \quad 3 \quad$ METHODS}

$348 \quad 3.1 \quad$ Processing and identification of charcoal

349 Soil samples were processed by flotation (O’Donnell 2007, 28). Charcoal was identified

350 following known standards (Marguerie and Hunot 2007; Schweingruber, 1978) and a

351 modern reference collection.

$353 \quad 3.2 \quad$ Subsampling of charcoal from available material 
354 Small (c. $2 \mathrm{~cm}$ longitudinally) charcoal fragments, as well as fine charcoal dust were sub-

355 sampled and reflectance measurements taken as follows:

364 Some differences are notable within the sub-soils from the three sites, although these are not thought to have affected charcoal preservation. At Templenoe, the sub-soil was dark boulder clay (Doody, 2008). At Lissava, the sub-soil was an orange-yellow gravely, sandy clays (Molloy, 2007). At Ballylegan, the sub-soil was compact, yellow brown sandy clay (Mc Quade, 2007). Soil pH was not recorded at the sites. Modern experimentation has shown that highly alkaline environments (such as may exist from high concentrations of ash from combustion of wood) can weaken charcoal structure, suggesting lower reflectance values may be observed (Braadbaart et al., 2009). Ash not noted from Templenoe, and the context descriptions of the cremation deposits are very

373 cohesive, indicating they were filled with loose, black silty clay (Doody, 2008). Even if

374 high alkalinity were present at burial it is difficult to know the rate/range of $\mathrm{pH}$ changes

375 that may have occurred due to percolation of rainwater, and/or groundwater over time.

\subsection{Reflectance testing in two stages}

378 Taxonomically identified charcoals $>2 \mathrm{~mm}$ identified were roughly crushed and mounted

379 in one of two methods (cold set, or hot set epoxy), highly polished, and inspected at

380 x1,000 magnification using a reflecting Nikon microphot microscope. Fifty

381 measurements were taken and averaged for each individual sample. The hot and cold set

382 epoxy methods have different utility depending on sample size and other factors, but a

383 control test revealed results were not affected by setting method. The samples here were

384 prepared both by cold set ( $>2 \mathrm{~mm}$ samples), and hot set $(250 \mu \mathrm{m}-2 \mathrm{~mm}$ samples). In the hot 
set method, careful selection of the ratio of charcoal dust to epoxy powder is needed. Too

386 much epoxy powder results in insufficient charcoal at the sample interface; too little

387 epoxy results in a gritty sample that is difficult to polish. A ratio of about $1 / 3$ charcoal

388 dust to $2 / 3$ epoxy mix was found to be suitable for these samples. (Further method details

389 can be found in Supplementary materials 1)

391 Testing of samples of individual and mixed taxa was carried out. In a second round of

392 measurements, smaller charcoals of various fraction sizes were tested (from the same

393 contexts). Table 1 details the characteristics of the charcoals tested and the reflectance

394 results. Sample numbers are not contiguous as some failed to be 'readable' for reflectance

395 after preparation due to the challenges of sample preparation, in particular, the need to

396 provide at the end of the process good exposure of the charcoal to the reflecting laser, i.e.

397 at the very uppermost surface of the resin.

\subsection{Reporting reflectance results: average and maximum temperatures}

401 Standard procedure in past reflectance testing has reported ranges of average

402 temperatures (calculated from 50-100 measurements of each individual sample). Here

403 we follow convention, but also consider more critically, the maximum temperatures

404 observed for each sample. Temperatures were inferred using a 1, 6, 12 and 24 hour

405 calibration curve developed by MacParland for Quercus (figure 1). Results are expressed

406 as a range of temperature e.g. a sample with a reflectance value of 5\%Ro would need to

407 be charred at $880{ }^{\circ} \mathrm{C}$ for one hour or $800{ }^{\circ} \mathrm{C}$ for 24 hours giving a range of $800-880{ }^{\circ} \mathrm{C}$.

408 The Quercus (deciduous) curve, was adopted as this was the most common wood

409 observed within the Irish archaeological samples. No experimentation has been carried

410 out on evergreen oak (a factor of relevance for Mediterranean data) and a wood that is

411 usually harder and of higher specific gravity.

413 Table 1: Context types, characteristics, and reflectance results of tested charcoals (using

414 McParland reflectance curve in fig. 1) 


\section{RESULTS}

\section{$419 \quad 4.1 \quad$ Summary}

420 In the first round of readings from $>2 \mathrm{~mm}$ sized charcoals, the average temperature varied 421 from a low of $360-410^{\circ} \mathrm{C}$ (Samples 7 and 10) to a high of $390-450^{\circ} \mathrm{C}$ (Sample 12) (table

422 1). The highest temperature observed was $525^{\circ} \mathrm{C}$ (Sample 3). Little or no variation could

423 be correlated with wood species. As these readings were well below those expected (650-

$424800^{\circ} \mathrm{C}$ ), a decision was made to seek smaller fraction charcoals (by way of dry sieving 425 the extant archaeological material). McParland et al. (2009a and b), Braadbart and Poole

426 (2008) and others suggest that due to the increasingly brittle nature of charcoals with 427 increased charring temperature, higher reflecting charcoals may be limited to the smallest 428 size fraction. Careful sieving was made of the sub $2 \mathrm{~mm}$ charcoals into $2-1 \mathrm{~mm}, 1 \mathrm{~mm}-500$ $429 \mu \mathrm{m}$, and 500-250 $\mu \mathrm{m}$ fractions (however, subsequently these sub-divisions provided no 430 extra information). As the flotation material kept was processed over a $250 \mu \mathrm{m}$ mesh, it 431 was possible to examine material as small as this, but no smaller, from the same contexts 432 from which the identified charcoals arose. It cannot be proven that the charcoals in the 433 range $250 \mu \mathrm{m}-2 \mathrm{~mm}$ are the same wood types, but it is highly probable (in any event, 434 wood type was determined to have little bearing on the process). It should also be borne 435 in mind that the size of a particular charcoal fragment may not only be due to fire 436 process, but also to depositional and taphonomic phenomena, and excavation and post-

437 excavation handling. All result in further fragmentation of archaeological charcoal.

439 In the second round of readings from the $>250 \mu \mathrm{m}-2 \mathrm{~mm}$ fractions, average

440 temperatures ranged from a low of $360-410^{\circ} \mathrm{C}$ (Sample 26, correlating with Samples 2

441 and 27) to an average temperature high of $390-450^{\circ} \mathrm{C}$ (Sample 19, correlating with

442 Sample 9). The highest temperature recorded was $515^{\circ} \mathrm{C}$ (Sample 27, correlating with

443 Samples 2 and 26).

444

445 Thus the lowest and highest average temperatures are the same from the $>2 \mathrm{~mm}$, and $446>250 \mu \mathrm{m}-2 \mathrm{~mm}$ fractions $\left(360-410^{\circ} \mathrm{C} / 390-450^{\circ} \mathrm{C}\right)$. In some cases, the $>250 \mu \mathrm{m}-2 \mathrm{~mm}$ 
447 fraction actually provided a lower average temperature than the $>2 \mathrm{~mm}$ fraction (for

448 example Sample 26, correlating with Sample 2). A slight temperature increase can be

449 noted however, within the average temperatures of the smaller fraction samples than the

450 larger ones as shown in table 1. Observation showed that the difference between

451 'successful' and 'less successful' cremations as determined by bone colour could not be

452 explained by a difference in the calorific potential of the woods.

454 One of the questions considered was whether changes in temperature would be noted

455 from different archaeological contexts. Would a cremation pyre of mixed wood taxa (a

456 specialised construction with increased body fats) burn at a higher temperature than

457 domestic fires of mixed wood taxa? To test this, controls were taken measuring

458 reflectance values from Templenoe (Grave pit F179, Domestic pit F33), Lissava (Trough

459 pit F12) and and Ballylegan (Hearth F446). Average reflectance results from the mixed

460 taxa group of the grave pit from Templenoe (Sample 5) were $370-415^{\circ} \mathrm{C}$, and these do

461 not differ to those obtained from the domestic hearth at Ballylegan (Sample 11). Results

462 from the domestic pit at Templenoe F33 (Sample 8) are slightly higher, at $375-425^{\circ} \mathrm{C}$.

463 The highest temperature from this comparative group is $390-450^{\circ} \mathrm{C}$ (Sample 12) from the

464 trough fill at Lissava.

466 Table 2 summarises the maximum temperatures observed for each deposit type,

467 comparing contexts containing bone, with those that did not, or were the controls of

468 hearth and trough. Inspecting this table shows that generally the contexts with bone have

469 slightly higher temperatures, the maximum reading for contexts with bone was $525^{\circ} \mathrm{C}$,

470 and for those of the controls/ no bone: $490^{\circ} \mathrm{C}$, but the difference is marginal. More data,

471 and/or employing a reflectance reading strategy that uses Rmax proper (i.e. with the

472 transverse section aligned perpendicularly for the 'best' possible reading), as opposed to

$473 \%$ Ro (average random readings, on unaligned sections) may provide higher temperature

474 readings.

476 Table 2: Comparison of maximum temperatures observed in contexts with bone, and 477 without bone 
478

479 


\subsection{Reconsidering calibration curves}

483 The temperatures measured using reflectance on the cremation deposits are lower than

484 expected. This may be linked to the current available calibration curves.

485 A number of studies have published calibration graphs of the temperature / random

486 reflectance relationship with a positive correlation between increasing temperature of

487 formation and increasing mean random reflectance (\%Ro) (Ascough et al., 2010;

488 Braadbaart and Poole, 2008; Bustin and Guo, 1999; Guo and Bustin, 1998; Jones et al.,

489 .1991; McParland et al. 2007; Scott and Jones 1991; Scott and Glasspool 2005).

490 The curves are in broad agreement, but they were each constructed using different woods

491 and under a variety of conditions. Woods studied included: (conifers) Sequoia

492 sempervirens, Pseudotsuga menziesii, Picea abies and Pinus sylvestris; (decidous

493 broadleaves); Quercus robur, Fagus sylvatica, Corylus avellana and Alnus glutinosa.

494 The two curves developed by Bustin and Guo (1999) and Guo and Bustin (1998) aimed

495 to measure $R \max$ (i.e. by carefully orienting the samples to provide a transverse surface

496 exactly perpendicular to the incident light), while the rest of the studies examine \%Ro

497 (average random reflectance - without special orientation of the sample).

499 McParland (2010, table 10.1) provides a detailed table comparing these studies, however, 500 among all of theses studies, it is only her own that attempts measurements across five 501 taxa, while all the others create curves using just one taxon. Comparison of the studies is

502 further complicated by the fact that different researchers formalise calibration

503 measurement points at different temperatures. Table 3 summarises the maximum

504 variation observed in \%Ro where four or more comparanda readings are available, except

505 for those measurements from $700-1100^{\circ} \mathrm{C}$, where the low reading is always from

506 McParland (2010), while the higher reading is from Braadbart and Poole (2008). Figure

5074 illustrates the comparison of these latter two curves, and exemplifies how at one \%Ro,

508 quite a range of temperatures are theoretically possible. These are the only two

509 calibration curves which to date examine oak. Differences in the reported mean random

510 reflectance at a given formation temperature and duration may be accounted for by 
511 variable factors in different experiment designs, such as length of seasoning time of the

512 calibration wood, dimensions of the sample material charred, or differences in charring

513 protocol (for example, charring under nitrogen atmosphere, which results in complete

514 exclusion of oxygen; or charring by wrapping in aluminium foil, a 'low' oxygen method).

515 It may be that differences in polishing level, and/or calibration of differing laboratory

516 reflectance systems may also account for these variations, as well as the fact that all

517 measure \%Ro (i.e. the average of the maxima and minima observed - without perfect

518 alignment of the transverse plane). In figure 4, Braadbart and Poole's 2008 curve, the

519 reflectance values as observed in this experiment result in temperature readings that can

520 be as much as $150^{\circ} \mathrm{C}$ higher for the same reflectance value. McParland et al.'s (2010)

521 preparatory methods however more closely mimic actual ancient fire conditions: low

522 oxygen charring, over a variety of time periods, and, importantly, across a range of taxa

523 most often found in European charcoal assemblages, thus this curve has been used in

524 calibrating the reflectance results for this study. Calibration curves built on, for example,

525 sequoia, or other conifers (summarised well in Scott et al. 2014:section 2.4) may have

526 little relevance to European conditions (although sequoia of course may be useful in

527 American studies). A further new curve is found in Hudspith (2015:3) who also measures

528 reflectance of multiple woods types: Betula nana, Picea mariana, Picea glauca, Betula

529 papyrifera and Populus tremuloides (figure 5). These taxa were chosen for their

530 relevance in the modern wildfire study to which she applies her curve-The resinous

531 nature of conifers (as opposed to hardwoods) may affect calibration due to the possibile

532 recondensation of resins during charcoalification, however no recognisable pattern of

533 reflectance calibration curves could be discerned that distinguished conifers from

534 broadleafed species, although wood specific gravity did seem to have some influence

535 (higher SGs give higher reflectance at a given temperature).

537 Table 3: Variation in reflectance measurements from six different studies (from

538 McParland 2010, table 10.1). Studies of: Ascough et al., 2010; Braadbaart and Poole,

539 2008; Bustin and Guo, 1999; Guo and Bustin, 1998; Jones et al., .1991; McParland et al.

540 2007; Scott and Jones 1991; Scott and Glasspool 2005. Table shows \%Ro where four or

541 more comparanda readings were available, except for those measurements from 700- 
$5421100^{\circ} \mathrm{C}$, where the low reading is always from McParland (2010), while the higher

543 reading is from Braadbart and Poole (2008).

545 As noted, Braadbart and Poole (2008) is the only other study which derives a curve from

546 Quercus, but they used very small cubes of wood which were charred only for an hour

547 (conditions unlikely to mimic the long process of cremation), however, their remarks on

548 this curve bear some examination. Firstly, they note that a higher rate of increase of

549 reflectance (and therefore temperature) lies in the range $600-850^{\circ} \mathrm{C}$ (so their curve is not

550 completely 'flat'). They also note a tailing off of reflectance values after $850^{\circ} \mathrm{C}$, and at

551 this temperature we may expect (as they note) that if full combustion has occurred, then

552 in all likelihood there will be very little carbonised material to observe in the imperfect

553 and variable conditions of reality (as opposed to laboratory) burning. Testing of small

554 microcharcoals from inside iron slag (Veal et al., in preparation), has had some success

555 however, with reflectance values translating into temperatures over $1000^{\circ} \mathrm{C}$. The fact

556 that the 'best' calibration curve may not in fact be linear, is also demonstrated by the

557 most recently published work by Hudspith et al. (2015, Fig. 5) whose fitted curve is $\mathrm{S}$

558 shaped., but whose raw data points closely follow the patterns of McParland (2010) and

559 Braadbaart \& Poole (2008)

561 Figure 4 : Braadbart and Poole's (2008) calibration curve and that of McParland (2010).

562 Both derived from Quercus, although with very different preparation strategies.

564 Figure 5 : Hudspith et al.'s (2015) calibration curve for five experimentally charred

565 (American) boreal woods. Mean random reflectance under oil (Romean) and standard

566 deviations represent all species. Derived from charring small pieces of wood for 1 hour

567 each at varying temperatures.

571 According to the calibration curve we believe to be most appropriate to the burning

572 conditions of cremation (Mc Parland , 2010), the results (average temperature high of 
$573390-450^{\circ} \mathrm{C}$ ) show that charcoals collected above $250 \mu \mathrm{m}$ from known pyre contexts have 574 not demonstrated the temperatures associated with cremation (above $650^{\circ} \mathrm{C}$ as previously

575 discussed). A range of variable results were obtained, with, in some cases a small upward

576 trend for the smaller fraction charcoals. Reading from alternatives curves, such as that of

577 Braadbaart and Poole (2008), however, the temperatures expected may be inferred in a

578 range around and above $650^{\circ} \mathrm{C}$. This demonstrates how the calibration curve used can

579 greatly influence results and calls for greater agreement in calibration curves.

581 A number of explanations may be considered:

582 - Is the reflectance method capable of measuring temperatures in archaeological

583 charcoals as high as $650-800^{\circ} \mathrm{C}$ ? Experimental work creating charcoal under

584 laboratory conditions indicates that temperatures up to $1,100^{\circ} \mathrm{C}$ can be measured

585 through reflectance (Mc Parland et al., 2009a, 253). When applied to archaeological

586 materials, however, average measured temperature values reported to date are 330-

$587410^{\circ} \mathrm{C}$ (Mc Parland et al., 2009b, 182) and 375-530 ${ }^{\circ} \mathrm{C}$ (Mc Parland et al., 2009a, 6).

588 Further work must be conducted on measuring reflectance values from archaeological

589 charcoal to demonstrate the maximum temperatures the method can record.

590 - The collected remains may reflect fuel waste located at the periphery of the fire, (i.e.

591 the cooler part of it), and/or which had been thrown on late in the cremation (and thus

592 not exposed to the high central pyre temperature.) The cremated remains, ash and

593 charcoal are however, culturally sorted before deposition in an urn or grave, which

594 ultimately contains selected bones and some charcoal, a process which will have

595 likely mixed the remains, so selective collection by the archaeologist of lower

596 temperature (only) exposed charcoals seems improbable.

597 - Higher temperature charcoals tend to be more brittle and vulnerable to breakage, as

598 noted, and therefore there is likely to be a bias towards lower temperature materials in

599 any identified charcoal assemblage (the smaller the material size, the more probable it

600 will be lost in surrounding soils, and/or not collected).

601 - The collected remains may have reached the temperature of cremation, but the

602 taphonomic processes over c. 3500 years (such as percolation or mineralisation), have

603 altered the reflectance of the charcoal. Fresh breaks are revealed before reflectance 
measurements are taken making this possibility less probable in the case of external

605 mineralisation, however, highly acid or alkaline waterlogged sites (not indicated

606 here), may be problematic. Generally speaking, archaeological charcoals absorb

607 chemicals in soils around them, and in particular water, diagenesis of charcoal does

608 occur over long time periods, and more testing of this phenomena through chemical

609 and physical proxies, as well as reflectance, may assist.

- While the smaller, (i.e. $250 \mu \mathrm{m}$ ) charcoals mostly did reveal a slight increase, the change in average temperature was not statistically significant. Higher temperatures may be measureable from even smaller material, therefore this needs collection by way of un-sieved ash/charcoal/soil samples, although if combustion is virtually complete, no remains may be archaeologically detectable, as also noted by Braadbaart and Poole (2008) and others. This will depend on the origins of the charcoal, and the manner of collection

621 The results suggest that reflectance will need to be applied in a selective manner and

622 results interpreted carefully in terms of cultural practice, combustion processes and

623 taphonomy. Reflectance results outlined here (according to our chosen calibration curve)

624 do not match those expected from cremation deposits, however, they reach the minimum

625 temperature expected using the curve of Braadbaart and Poole (2008). We have not used

626 this curve because its development involved preparation methods less close to those of

627 prehistoric cremation, as already noted.

629 The calibration curve used here, and others published elsewhere need to be further 630 refined so we can obtain well-tested curves for major archaeological fuel woods 631 (predominantly hardwoods). The calibration line of best fit may well be a curve, rather 632 than a straight line relationship. The apparent steeper rise in reflectance from about 550$633600{ }^{\circ} \mathrm{C}$, needs to be investigated, and we suggest may relate to a particular state of 634 rearrangement of the carbon atoms and aromatic compounds within the charcoal. 
636 Exchange of samples for testing in different laboratories will assist, together with

637 checking of standards used. To this end it is suggested that a group of researchers be

638 formed to test and agree a way forward.

640 Ultimately the science of reflectance may require nuanced calibration of curves for

641 different taxonomic groups, and perhaps according to anatomical structure to see if

642 resolution of estimated temperature may be improved beyond the $100-150^{\circ} \mathrm{C}$ range

643 currently observed. Testing of other charred materials (such as seeds) is underway as

644 olive and grape pressings are also found as fuels, see for example, Braadbaart et al.

645 (2016), Rowan (forthcoming), Coubray et al. (forthcoming). The diagenesis of charcoal

646 increases over time, and this needs further examination, perhaps by way of examining

647 other chemical and physical propeorties of differently aged archaeological charcoal.

649 Combustion, once temperatures reach the high levels expected, may be wholly

650 destructive under some fire regimes, and it may not be possible to collect any remnant

651 charcoals that have been exposed to the high temperatures, although testing of reflectance

652 on charcoals from an iron smelting site in Medieval Angkor (South East Asia) has shown

653 more encouraging results, with some results ca. $1000^{\circ} \mathrm{C}$ (Veal et al in preparation).

654 Testing of small materials would be desirable. Normal field collection of charcoal is by

655 dry sieving over 4 or $5 \mathrm{~mm}$ mesh, and/or flotation over $250 \mu \mathrm{m}$ or larger mesh. The

656 absolute size of charcoal fragments for taxonomic identification purposes is usually

$657>2 \mathrm{~mm}$. It will be useful in the future to collect un-sieved soil samples of ash and micro-

658 charcoals (where present), and separate the charcoal by gravimetric or other method for

659 reflectance testing to further resolve this issue. Small bulk samples collected by hand (we

660 suggest approximately $500 \mathrm{~g}$ would be adequate. These should be stored in a cool place,

661 and not subjected to changing ranges of temperature or moisture after excavation. As this

662 strategy also accords with that required for a range of archaeometric studies, its burden to

663 the archaeologist would be minimal.

665 The method does have utility even at this level of refinement as it appears to differentiate 666 high and low level temperature processes. Further work using the reflectance method in 
667 other archaeological context types is also required, for instance, the testing of 'charcoal

668 only' fires, vs 'raw wood' fires, should provide contrasting temperature profiles.

669

\section{ACKNOWLEDGEMENTS}

671

672

The authors acknowledge the support of the CSIRO, Sydney; the Department of

673 Archaeology, and the Australian Centre for Microscopy and Microanalysis, University of

674 Sydney (especially materials preparation specialist, Mr Adam Sikorski); and the

675 McDonald Institute for Archaeological Research, University of Cambridge. Excavations

676 were carried out by Margaret Gowen \& Co. Ltd, funded by the National Roads Authority,

677 Ireland. This research was partly funded by the Government of Ireland, Irish Research

678 Council (Project id GOIPD/2013/387) supported by the School of Archaeology,

679 University College Dublin. Charcoal results are stored in the WODAN database at

680 www.wodan.ie.

681

682

683 
684

685

686 Ascough, P.L., Bird, M.I., Scott, A.C., Collinson, M.E., Cohen-Ofri, I., Snape, C.E. and

687 Le Manquais, K., 2010. Charcoal reflectance measurements: implications for

688 structural characterization and assessment of diagenetic alteration. Journal of

689 Archaeological Science 37, 1590- 1599.

690

691

692

693

694

695

696

697

698

699

700

701

702

703

704

705

706

707

708

709

710

711

712 Braadbaart, F., Poole, I., 2008. Morphological, Chemical and Physical Changes During

713 Charoalification of Wood and its Relevance to Archaeological Contexts, Journal of

714 Archaeological Science 35, 2434-2445. 
716 Braadbaart, F., Poole, I., and van Brussel, A.A., 2009. Preservation potential of charcoal

717 in alkaline environments: an experimental approach and implications for the

718 archaeological record. Journal of Archaeological Science 36, 1672-1679.

720 Braadbaart, F., Poole, I., Huisman, H.D.J. and van Os, B., 2012. Fuel, Fire and Heat: an experimental approach to highlight the potential of studying ash and char remains from

722 archaeological contexts. Journal of Archaeological Science 39, 836-847.

724 Braadbart, F., Wright, P. J., Vander Horst, J. and Boon, J. J., 2007. A laboratory

725 simulation of the carbonization of sunflower achenes and seeds. Journal of Analytical

726 and Applied Pyrolysis 78, 316-327.

728 Bustin RM. and Guo Y., 1999. Abrupt changes (jumps) in reflectance

729 values and chemical compositions of artificial charcoals and

730 inertinite in coals. Int J Coal Geol 38:237-260.

732 Chabal, L., 1992 La représentativité paléo-écologique des charbons de bois archéolgiques

733 issus du bois de feu. Bulletin de la Société Botanique de France 139, 213-236.

734 Chabal, L., Fabre, L., Terral, J.-F., Théry, I., 1999. L'anthracologie. In Bourquin-

735 Mignot, C., Brochier, J.-E., Chabal, L., Crozat, S., Fabre, L., Guibal, F., Marnival, P.,

736 Richard, H., Terral, J.-F. \& Théry, I. (Eds.) La Botanique. Paris: France.

738 Chrzavzez, J., Théry-Parisot, I., Terral, J.-F., Ducom, A. and Fiorucci, G., 2011.

739 Differential preservation of anthracological material and mechanical properties of wood

740 charcoal, an experimental approach of fragmentation, in: Badal, E., Carriòn, Y., Grau, E.,

741 Macías, M., Ntinou, M. (Eds.), 5th International Meeting of Charcoal Analysis. The

742 charcoal as cultural and biological heritage. Saguntum, Papeles del Laboratorio de

743 Arqueología de València, Department de Prehistòria i Arqueologia, València, 29-30.

745 Chrzavzez, J., Théry-Parisot, I. Fiorucci, G., Terral, J.F., and Thibaut, B., 2014. I'mpact

746 of post-depositional processes on charcoal fragmentation and archaeobotanical 
747 implications: experimental approach combining charcoal analysis and biomechanics.'

748 Journal of Archaeological Science 44, 30-42.

750 Coubray, S., V. Zech-Matterne, V. and Monteix N., forthcoming. 'Of Olives and Wood.

751 Baking Bread in Pompeii.' In Fuel and Fire in the Ancient Roman World: towards an

752 integrated economic understanding, edited by R. Veal and V. Leitch. Cambridge:

753 McDonald Institute for Archaeological Research Monographs.

755 Devlin, J.B. and Herrmann, N.P. 2008. Bone colour as an interpretive tool of the

756 depositional history of archaeological cremains. In The Analysis of Burned Human

757 Remains, edited by C.W. Schmidt and S.A. Symes (eds.) London: Elsevier Academic

758 Press, 109-128.

759

760 Dufraisse, A., 2006. Charcoal Analysis: New Analytical Tools and Methods for

761 Archaeology: Papers from the Table-Rhonde held in Basel 2004. BAR International

762 Series 1483. Oxford: Archaeopress.

764 Doody, M., 2008. Final report, Templenoe, Co. Tipperary. N8 Cashel to Mitchelstown 765 road scheme. Ministerial Direction Scheme Reference number A035/000. Registration 766 number E2290. Unpublished report for Margaret Gowen \& Co. Ltd.

768 Gale, R. 2003. Wood-based industrial fuels and their environmental impact. In Murphy, 769 P. and Wiltshire, P.E.J. (Eds.) The Environmental Archaeology of Industry. Symposia of 770 the Association of Environmental Archaeology No. 20. Oxford: Oxbow books.

773 Geber, J., 2008. The cremation burials from Templenoe (E2290). Unpublished report for 774 Margaret Gowen \& Co. Ltd. 
776 Geber, J. 2009. Chapter 7. The human remains. In M. McQuade, B. Molloy and C.

777 Moriarty (eds.) In the shadow of the Galtees. Archaeological excavations along the N8

778 Cashel to Mitchelstown. Dublin: The National Roads Authority, 209-240.

Guo, Y, and Bustin, R.M. 1998. FTIR spectroscopy and reflectance of modern charcoals and fungal decayed woods: implications for studies of inertinite in coals. Int $\mathrm{J} \mathrm{Coal} \mathrm{Geol}$ 37:29-53.

791

Harrison, K ., 2013. The application of forensic fire investigation techniques in the archaeological record. Journal of Archaeological Science 40:955-59.

Hudspith A., Belcher, C., Kelly R., and Hu, F.S., 2015. Charcoal Reflectance Reveals Early Holocene Boreal Deciduous Forests Burned at High Intensities. PloS One DOI:10.1371/journal.pone.0120835.

796 Lancelotti, C., Madella, M., P., A. and Petrie, C.A., 2010. Temperature, compression and 797 fragmentation: an experimental analysis to assess the impact of taphonomic processes on 798 charcoal preservation. Archaeological and Athropological Sciences 2, 307-320.

800 Ludemann, T., 2006. Anthracological Analysis of Recent Charcoal-Burning in the Black 801 Forest, SW Germany, in: Dufraisse, A. (Ed.), Charcoal Analysis: New Analytical Tools 802 and Methods for Archaeology, Archaeopress, Oxford, pp. 61-70.

804 Lynch, L.and O'Donnell, L., 2007. Cremation in the Bronze Age: Practice, process and

805 belief. In Grogan, E., O'Donnell, L. and Johnston, P. (Eds.) The Bronze Age Landscapes

806 of the Pipeline to the West: An integrated archaeological and environmental assessment. 807 Bray: Wordwell. 
809 Lyons, G., Lunny, F. and Pollock, H.P., 1985. A Procedure for Estimating the Value of

810 Forest Fuels. Biomass, 8, 283-300.

812 Marguerie, D. and Hunot, J.Y. 2007. Charcoal analysis and dendrology: data from

813 archaeological sites in north-western France. Journal of Archaeological Science 34,

$814 \quad 1417-1433$.

816 McKinley, J. , 1993. Bone fragment size and weight of bone from modern British

817 cremations and the implications for the interpretation of archaeological cremations.

818 International Journal of Osteoarchaeology, 3, 287-283.

820 McKinley, J., 2000. The analysis of cremated bone. In Cox, M. and Mays, S. (Eds.)

821 Human osteology in archaeology and forensic science. London: Greenwich Medical

822 Media Ltd, 403-421.

823

824 Mc Kinley, J. 2008. In the heat of the pyre: efficiency of oxidation in Romano-British

825 cremations - did it really matter? In C.W. Schmidt and S.A. Symes (eds.) The Analysis of

826 Burned Human Remains. London: Elsevier Academic Press, 163-184.

828 McParland, L., Collinson, M. E., Scott, A. C., Steart, D. C., Grassineau, N. V. and

829 Gibbons, S.. 2007. Fern and fires:experimental charring of ferns compared to wood and

830 implications for paleobiology, paleoecology, coal petrology and isotope geochemistry

831 PALAIOS 22, 528-538.

832

833 McParland, L., Collinson, E., Scott, A. and Campbell, G., 2009a. The use of reflectance

834 values for the interpretation of natural and anthropogenic charcoal assemblages.

835 Archaeological Anthropological Science 1, 249-261.

837 McParland, L., Hazell, Z., Campbell, G., Collinson, M. E. and Scott, A. C., 2009b. How

838 the Romans got themselves into hot water: temperatures and fuel types used in firing a

839 hypocaust. Environmental archaeology 14, 176-183. 
841 McParland, L.C., 2010. Utilisation of quantified reflectance values to determine

842 temperature and processes of formation for human produced charcoals . Ph.D. Thesis

843 (unpublished). Royal Holloway, University of London.

846 McParland, L., Collinson, M., Scott, A., Campbell, G. and Veal, R. 2010. Is vitrification

847 in charcoal a result of high temperature burning of wood? Journal of Archaeological

848 Science 37 1-9.

850 McQuade, M., 2007. Final report, Ballylegan, Co. Tipperary. N8 Cashel to Mitchelstown 851 road scheme. Ministerial Direction Scheme Reference number A035/000. Registration

852 number E2265. Unpublished report for Margaret Gowen \& Co. Ltd.

854 McQuade, M., Molloy, B., Moriarty, C., 2009. In the shadow of the Galtees

855 Archaeological excavations along the N8 Cashel to Mitchelstown. Dublin: The National 856 Roads Authority.

858 Molloy, B., 2007. Final report, Lissava, Co. Tipperary. N8 Cashel to Mitchelstown road 859 scheme. Ministerial Direction Scheme Reference number A035/000. Registration number 860 E2296. Unpublished report for Margaret Gowen \& Co. Ltd.

863 O'Donnell, L., 2007. Charcoal and wood. In: Grogan, E., O' Donnell, L.and Johnston, P.

864 (Eds.), The Bronze Age Landscapes of the Pipeline to the West. An integrated

865 archaeological and environmental assessment. Bray: Wordwell.

867 O’Donnell, L. 2011.People and woodlands, an investigation of charcoal remains as

868 indicators of cultural remains and environmental indicators in Bronze Age Ireland. $\mathrm{PhD}$

869 thesis, University College Dublin. 
871 O'Donnell, L. 2016. The power of the pyre - a holistic study of cremation focusing on

872 charcoal remains. Journal of Archaeological Science 65, 161-171.

873

874 Rowan, E. "The Energy Potential of Pomace Fuel in the Roman World." In Fuel and Fire

875 in the Ancient Roman World: Toward an Integrated Economic Understanding, edited by

876 R. Veal and V. Leitch. Cambridge: McDonald Institute for Archaeological Research

877 Monographs, forthcoming.

878

879 Schweingruber, F.H., 1978. Microscopic wood anatomy. Birmensdorf: Swiss Federal

880 Institute for Forest, Snow and Landscape Research.

881

882 Scott A.C. and Jones T.P. 1991. Microscopical observations of recent and

883 fossil charcoal. Microsc anal 24:13-15.

884

885 Scott A.C. and Glasspool I.J. 2005 Charcoal reflectance as a proxy for the

886 emplacement temperature of pyroclastic flow deposits. Geology. 33: 589-592.

888 Scott, A.C., Bowman, D.M.J.S., Bond, W.J., Pyne, S.J. and Alexander, M.E., 2014.

Fire on Earth: an Introduction. John Wiley \& Sons Ltd:Chichester.

891 Shipman, P., Foster, G. and Schoeninger, M. 1984. Burnt bones and teeth: an experimental study

892 of color, morphology, crystal structure and shrinkage. Journal of Archaeological Science 11,

893 Issue 4, 307-325.

894

895 Stace, C. 1997. New Flora of the British Isles. Second edition. Bath: The Bath Press.

897 Steiner, M.C. and Kuhn, S.L. 1995. Differential Burning, Recrystallization, and Fragmentation of

898 Archaeological Bone. Journal of Archaeological Science 22, 223-237

900 Théry-Parisot, I., Chabal, L. and Chrzavzez, J., 2010. Anthracology and taphonomy,

901 from wood gathering to charcoal analysis. A review of the taphonomic processes 
902 modifying charcoal assemblages, in archaeological contexts. Palaeogeography,

903 Palaeoclimatology, Palaeoecology 291, 142-153.

904

905 Toynbee, J..M.C., 1971. Death and burial in the Roman world. Cornell: Cornell

906 University Press.

907

908 Van Andringa, W.H, Duday, S., Lepetz, S.,, Joly, D. and Lind, T. 2013. Mourir à

909 Pompéi. Fouille d'un quartier funéraire de la nécropole romaine de Porta Nocera (2003-

910 2007). Rome: Collection de l'Ecole française de Rome, 2 vol.

911

912 Veal R.., 2012. From Context to Economy: charcoal and its unique potential in

913 archaeological interpretation: a case study from Pompeii, I.E. Schrüfer-Kolb (ed.), More

914 than just numbers? The role of science in Roman archaeology, Vol.91 (Journal of Roman

915 Archaeology Supplement.) Portsmouth: Journal of Roman Archaeology. 19-52.

916

917 Veal, R., L. McParland, L. and Hendrickson, M. (forthcoming). Testing the Temperature

918 of Archaeological Charcoals Using the Reflectance Method: A Proxy for Estimating

919 Operating Temperatures and Fuel Type of Medieval Iron Smelting Furnaces at Preah

920 Khan of Kompong Svay, Cambodia.

921

922 Wahl, J., 1982. Leichenbranduntersuchungen. Ein Überblick über die Bearbeitungs-

923 und Aussagemöglichkeiten von Brandgräbern. Prähistorische Zeitschrift 57, 2-125.

924

925

926

927

928

929

930

931 


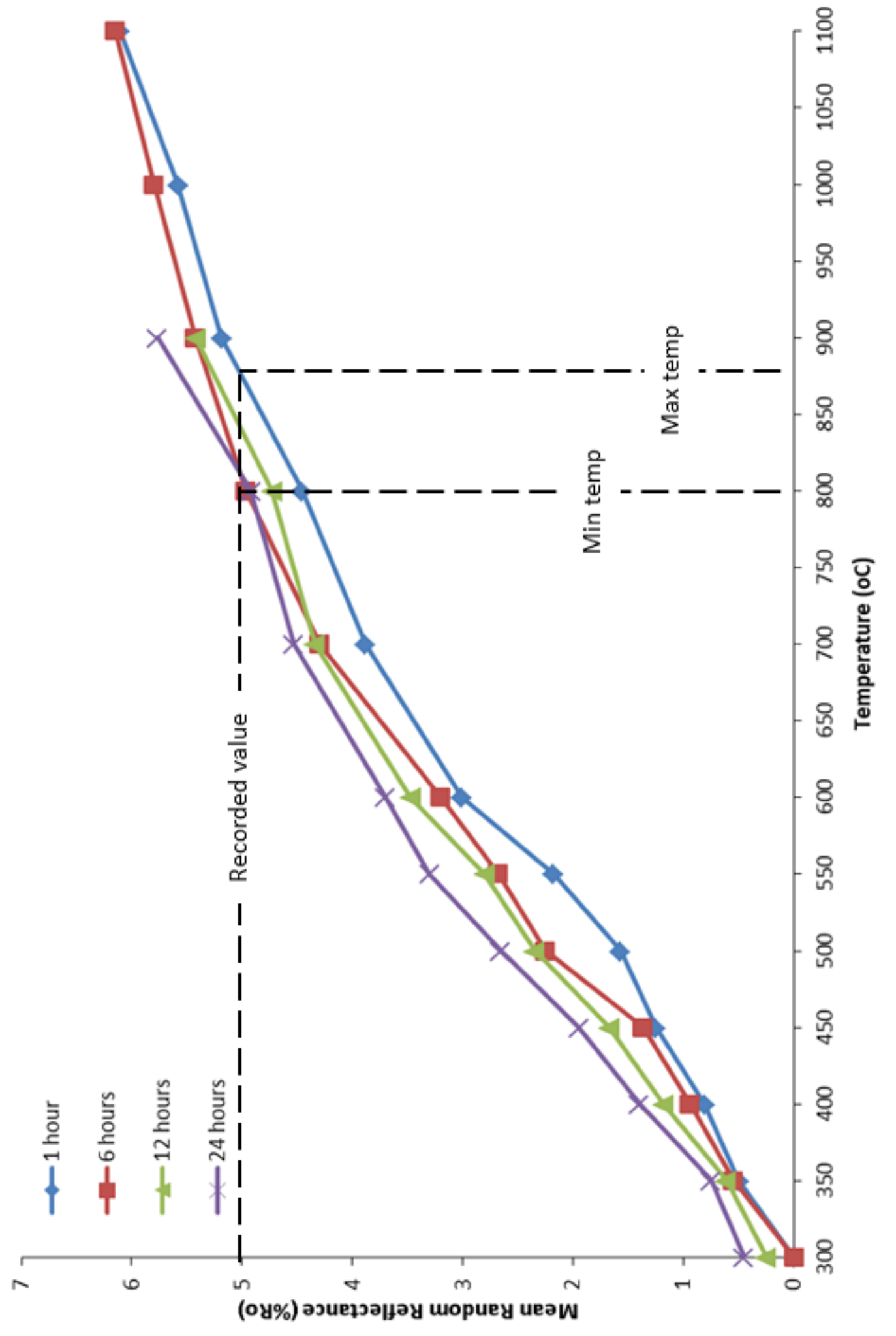




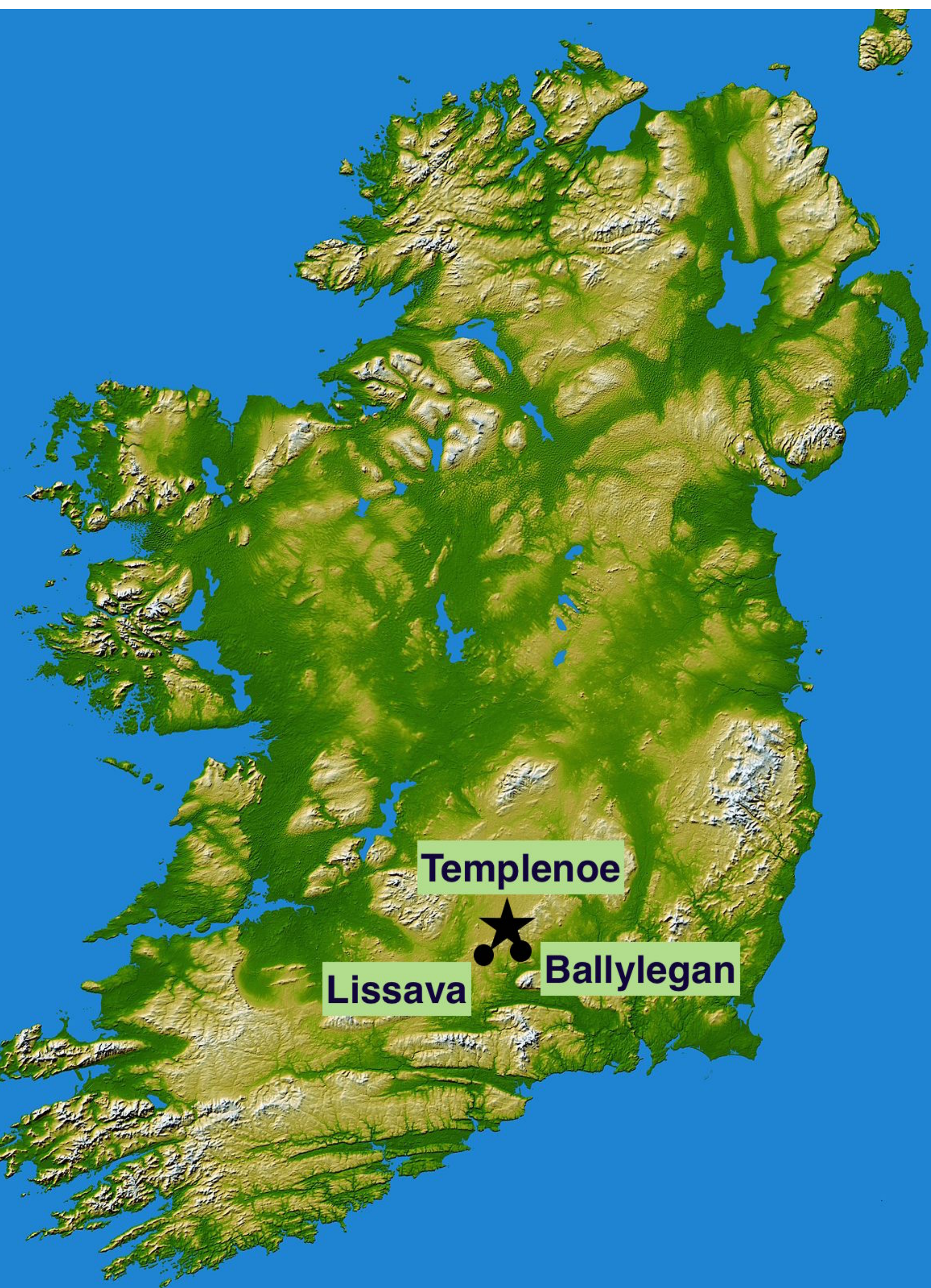




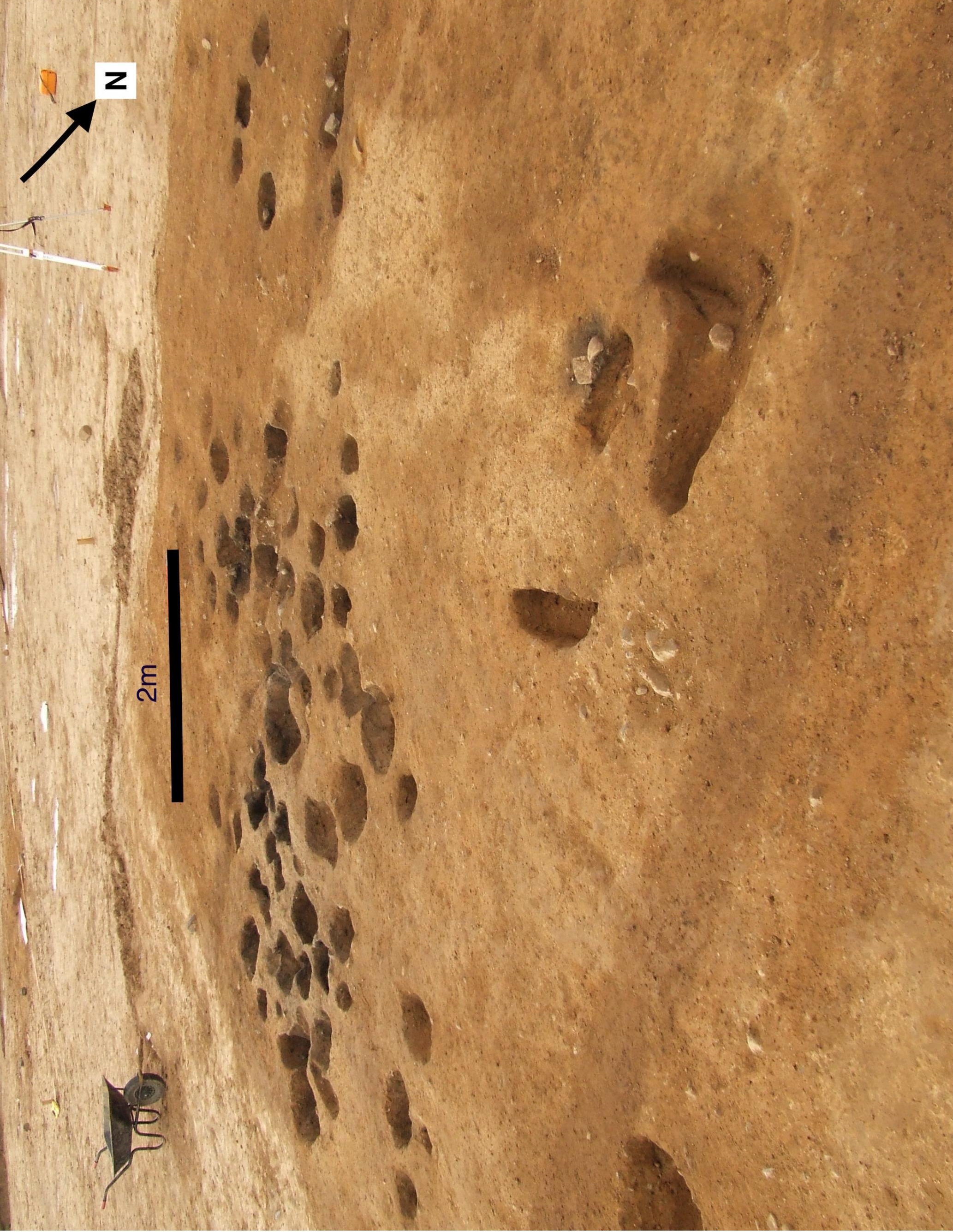




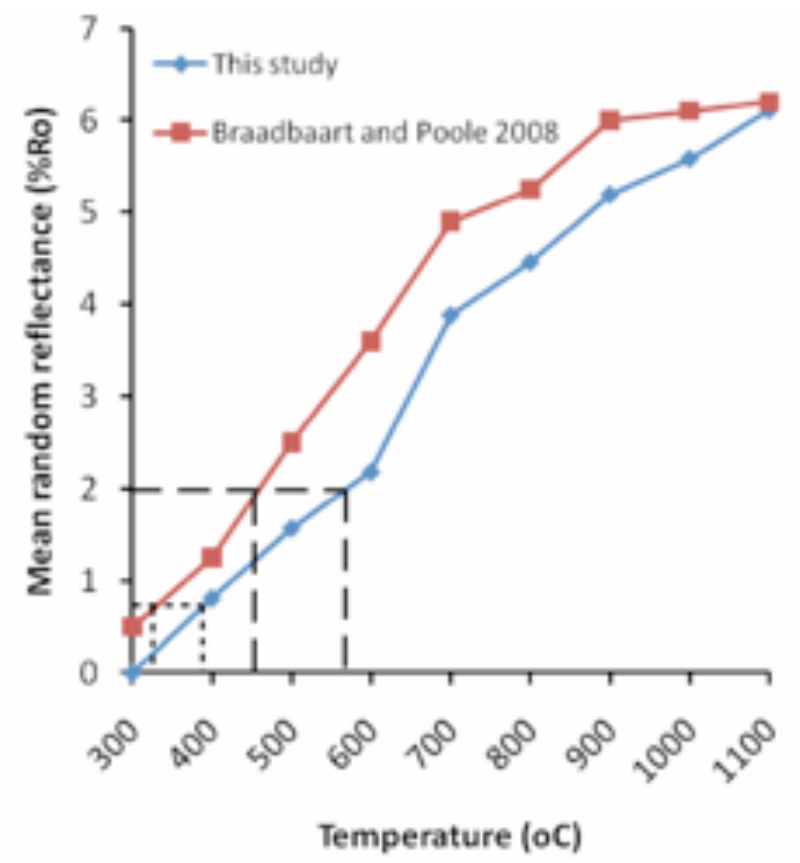




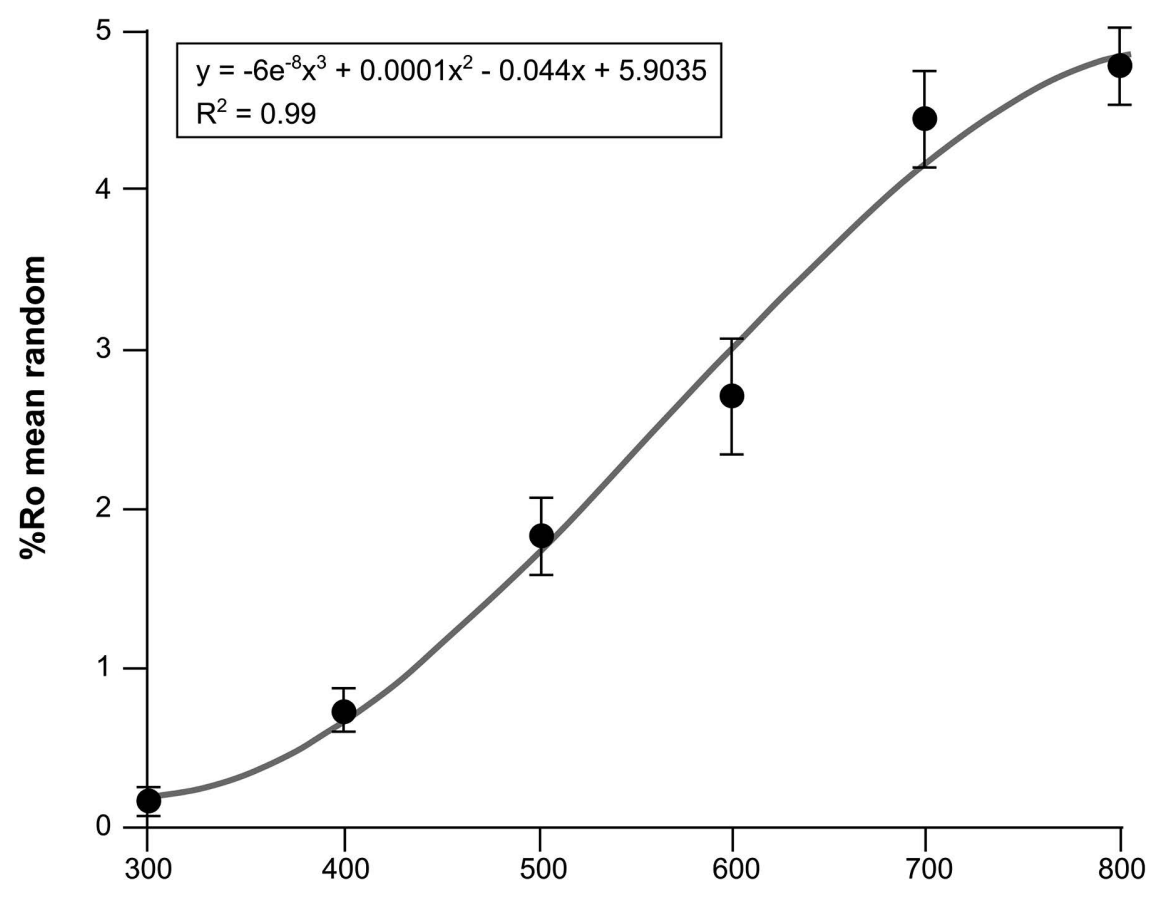

Charring Temperature $\left({ }^{\circ} \mathrm{C}\right)$ 


\begin{tabular}{|c|c|c|c|c|c|c|c|c|c|c|c|c|c|c|}
\hline Site & $\begin{array}{r}\text { Reflectance } \\
\text { sample no }\end{array}$ & \begin{tabular}{|} 
Feature No. \\
and type
\end{tabular} & Charcoal & Bone & $\begin{array}{l}\text { Bone } \\
\text { colour }\end{array}$ & \begin{tabular}{|l} 
Mean \\
reflect.
\end{tabular} & \begin{tabular}{|l} 
Min \\
reflect.
\end{tabular} & $\underset{\text { Max }}{\text { reflect. }}$ & \begin{tabular}{|c|} 
No. of \\
readings
\end{tabular} & SD & $\begin{array}{l}\text { Temp - } \\
\text { average } \\
\left({ }^{\circ} \mathrm{C}\right)\end{array}$ & $\begin{array}{c}\text { Temp - } \\
\max \\
\text { range } \\
\left({ }^{\circ} \mathrm{C}\right)\end{array}$ & $\begin{array}{c}\text { Absolute } \\
\text { max per } \\
\text { sample } \\
\left({ }^{\circ} \mathrm{C}\right)\end{array}$ & \begin{tabular}{|l} 
Absolute \\
max per \\
feature \\
('C)
\end{tabular} \\
\hline \multirow{16}{*}{ 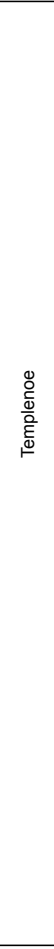 } & 1 & \multirow{2}{*}{$\begin{array}{c}141 \text { Grave } \\
\text { pit }\end{array}$} & $\begin{array}{l}\text { Maloideae C. Weber., } \\
\text { Quercus petraea (Mant.) } \\
\text { Liebl. Quercus robur L. }\end{array}$ & Human & White & 1.00 & 0.67 & 1.60 & 50 & 0.22 & $375-425$ & $325-510$ & 510 & \multirow[t]{2}{*}{510} \\
\hline & 22 & & Fine dust $>250 \mu \mathrm{m}$ & Human & White & 1.20 & 0.90 & 1.38 & 50 & 0.13 & $390-440$ & $360-475$ & 475 & \\
\hline & 2 & \multirow{3}{*}{$\begin{array}{c}133 \text { Grave } \\
\text { pit }\end{array}$} & $\begin{array}{l}\text { Maloideae C. Weber., } \\
\text { Fraxinus excelsior L. }\end{array}$ & Human & $\begin{array}{l}\text { Grey- } \\
\text { white }\end{array}$ & 1.07 & 0.67 & 1.41 & 50 & 0.18 & $380-430$ & $325-475$ & 475 & \multirow{3}{*}{515} \\
\hline & 26 & & Fine dust $>250 \mu \mathrm{m}$ & Human & $\begin{array}{l}\text { Grey- } \\
\text { white }\end{array}$ & 0.87 & 0.67 & 1.15 & 50 & 0.11 & $360-410$ & $325-440$ & 440 & \\
\hline & 27 & & Fine dust $>250 \mu \mathrm{m}$ & Human & $\begin{array}{l}\text { Grey- } \\
\text { white }\end{array}$ & 1.15 & 0.63 & 1.67 & 50 & 0.26 & $385-430$ & $325-515$ & 515 & \\
\hline & 3 & \multirow{4}{*}{$\underset{\text { pit }}{179 \text { Grave }}$} & $\begin{array}{l}\text { Quercus petraea (Matt.) } \\
\text { Liebl. Quercus robur L. }\end{array}$ & Human & White & 1.12 & 0.59 & 1.83 & 50 & 0.38 & $385-430$ & $325-525$ & 525 & \multirow{4}{*}{525} \\
\hline & 4 & & Maloideae C. Weber sp. & Human & White & 1.14 & 0.73 & 1.52 & 50 & 0.21 & $385-430$ & $345-490$ & 490 & \\
\hline & 24 & & Fine dust $>250 \mu \mathrm{m}$ & Human & White & 1.01 & 0.59 & 1.53 & 50 & 0.27 & $375-425$ & $325-500$ & 500 & \\
\hline & 5 & & \begin{tabular}{|l} 
Maloideae C. Weber. \& \\
Quercus petraea (Mantt). \\
Liebl. Quercus robur L.
\end{tabular} & Human & White & 0.97 & 0.55 & 1.18 & 50 & 0.15 & $370-415$ & $325-440$ & 440 & \\
\hline & 6 & \multirow{2}{*}{$\underset{\text { pit }}{207 \text { Grave }}$} & \begin{tabular}{|c|} 
Corylus avellana L., \\
Maloideae C. Weber., \\
Ulmus glabra Huds. \\
\end{tabular} & Human & $\begin{array}{l}\text { Grey- } \\
\text { white }\end{array}$ & 0.96 & 0.56 & 1.49 & 50 & 0.21 & $370-415$ & $325-490$ & 490 & \multirow[t]{2}{*}{490} \\
\hline & 25 & & Fine dust $>250 \mu \mathrm{m}$ & Human & $\begin{array}{l}\text { Grey- } \\
\text { white }\end{array}$ & 1.10 & 0.67 & 1.47 & 50 & 0.22 & $385-430$ & $325-490$ & 490 & \\
\hline & 7 & $\begin{array}{c}265 \text { Grave } \\
\text { pit }\end{array}$ & \begin{tabular}{|l|} 
Quercus petraea (Matt.) \\
Liebl. Quercus roburt., \\
Maloideae C. Weber.
\end{tabular} & Human & White & 0.90 & 0.56 & 1.12 & 50 & 0.14 & $360-410$ & $325-430$ & 430 & 430 \\
\hline & 8 & $\begin{array}{c}33 \text { Domestic } \\
\text { pit }\end{array}$ & \begin{tabular}{|c|} 
Maloideae C. Weber., \\
Corylus avellana L, Ilex \\
aquifolium L., Prunus \\
spinosa L. \\
\end{tabular} & No bone & & 1.05 & 0.88 & 1.30 & 50 & 0.09 & $375-425$ & $360-460$ & 460 & 460 \\
\hline & 9 & \multirow{2}{*}{$\underset{\text { pit }}{193 \text { Grave }}$} & $\begin{array}{l}\text { Quercus petraea (Matt.) } \\
\text { Liebl. Quercus robur L. }\end{array}$ & \begin{tabular}{|c|} 
Human \\
(older \\
adult)
\end{tabular} & White & 1.09 & 0.68 & 1.35 & 50 & 0.16 & $380-430$ & $325-470$ & 470 & \multirow{2}{*}{500} \\
\hline & 19 & & Fine dust >250 $\mu \mathrm{m}$ & $\begin{array}{l}\text { Human } \\
\text { (older } \\
\text { adult) } \\
\end{array}$ & White & 1.26 & 0.93 & 1.56 & 50 & 0.16 & $390-450$ & $360-500$ & 500 & \\
\hline & 10 & $\begin{array}{c}199 \\
\text { Possible } \\
\text { pyre }\end{array}$ & $\begin{array}{l}\text { Quercus petraea (Matt.) } \\
\text { Liebl. Quercus robur L. }\end{array}$ & No bone & & 0.89 & 0.68 & 1.15 & 50 & 0.12 & $360-410$ & $325-435$ & 435 & 435 \\
\hline 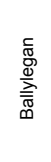 & 11 & 446 Hearth & $\begin{array}{l}\text { Prunus Prunus avium L. } \\
\text { (L.) Prunus padus L., } \\
\text { Salix L., Alnus glutinosa } \\
\text { (L.) Gaerth., Euonymous } \\
\text { L.., Maloideae C. Weber., } \\
\text { Quercus petraea (Matt.) } \\
\text { Liebl. Quercus robur L. }\end{array}$ & & & 0.97 & 0.48 & 1.48 & 50 & 0.20 & $370-415$ & $325-480$ & 480 & 480 \\
\hline 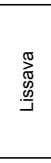 & 12 & 12 Trough & \begin{tabular}{|c|} 
Maloideae C. Weber., \\
Quercus petraea (Matt.) \\
Liebl. Quercus robur L., \\
Fraxinus excelsior L., \\
Ulmus glabra Huds., \\
Corylus avellana L., \\
Salix L.
\end{tabular} & & & 1.25 & 0.85 & 1.50 & 50 & 0.15 & $390-450$ & $355-490$ & 490 & 490 \\
\hline
\end{tabular}




\begin{tabular}{|c|c|c|c|}
\hline & Feature No. and type & $\begin{array}{c}\text { Absolute max per } \\
\text { feature containing } \\
\text { bone }\left({ }^{\circ} \mathrm{C}\right)\end{array}$ & $\begin{array}{c}\text { Absolute max } \\
\text { temp. per feature } \\
\text { - no bone }\left({ }^{\circ} \mathrm{C}\right)\end{array}$ \\
\hline \multirow{8}{*}{ 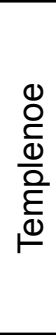 } & 141 Grave pit & 510 & \\
\hline & 133 Grave pit & 515 & \\
\hline & 179 Grave pit & 525 & \\
\hline & 207 Grave pit & 490 & \\
\hline & 265 Grave pit & 430 & \\
\hline & 33 Domestic pit & & 460 \\
\hline & 193 Grave pit & 500 & \\
\hline & 199 Possible pyre & & 435 \\
\hline 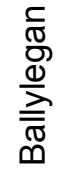 & 446 Hearth & & 480 \\
\hline 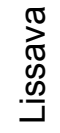 & 12 Trough & & 490 \\
\hline
\end{tabular}




\begin{tabular}{|c|c|c|}
\hline Temperature $\left({ }^{\circ} \mathrm{C}\right)$ & Low/High \%Ro & Maximum \%Ro variation \\
\hline 300 & $0-1.2$ & 1.2 \\
\hline 350 & $0.26-1$ & 0.83 \\
\hline 400 & $0.6-2$ & 1.4 \\
\hline 450 & $1.05-1.4$ & 0.35 \\
\hline 500 & $1.39-2.5$ & 1.81 \\
\hline 550 & $2.1-2.6$ & 0.5 \\
\hline 600 & $2.65-3.85$ & 1.2 \\
\hline $700^{*}$ & $3.15-4.9$ & 1.75 \\
\hline $800^{*}$ & $3.71-5.4$ & 1.69 \\
\hline $900^{*}$ & $4.95-6$ & 1.05 \\
\hline $1000^{*}$ & $5.23-6.1$ & 0.29 \\
\hline $1100^{*}$ & $5.91-6.2$ & 0.26 \\
\hline
\end{tabular}




\section{Overview of reflectance}

Reflectance testing has been adopted in coal assaying where it is standardized and used to rank coal quality (see for example https://www.astm.org/Standards/D7708.htm).

Charcoal also has an exceptional ability to reflect light when viewed using reflectance microscopy. The amount of light reflected is variable depending on the differential ordering of graphite-like phases within the charcoal itself. The charcoal's carbon atoms organize into an increasingly regular matrix over time. An analogous process is that of the less regular structure of graphite, progressing to the highly organized structure of diamond gradually over time, and with heat and pressure. In charcoal it has been demonstrated that this relates to the temperature of formation, whereby higher (absolute) formation temperatures result in higher charcoal reflectance (due to the more formal ordering of the carbon atoms). Cell wall fusion or homogenization may also play a role. This phenomenon occurs above $325^{\circ} \mathrm{C}$ (Scott and Glasspool, 2005; McParland et al. 2007, 2009a, 2009b). Testing the reflectance of charcoal, (as for coal), requires collection and mounting of samples in resin. Transverse sections of each of the fragments of charcoal are embedded in polyester resin and polished to a highly smooth surface. In this study, two methods were employed, cold and hot set. The cold set method requires careful manual placement of charcoals at the base of a mould, followed by mixing and pouring in of two part epoxy resin, (without disturbing the sample), and curation (about 24 hours), before careful polishing. The automated hot epoxy method raises the materials to no more than $80^{\circ} \mathrm{C}$. Resin tablets can be prepared in about 15 minutes from powdered epoxy, (Citopress hot press) and polishing can be more automated so as to polish multiple samples at once, thus reducing preparation time. At the Materials Laboratory at the University of Sydney, six samples were polished simultaneously, (Struers equipment, using increasingly fine grinding surfaces) allowing complete preparation of six samples in about two hours. Reflectance is measured using a reflecting microscope (in this case, the Nikon microphot microscope attached to Leica QWin image analysis software (Leica Image systems Ltd., 1997). Specimens are measured under Cargill immersion oil (refractive index, Ro, of 1.518 at $23^{\circ} \mathrm{C}$ ), using the $\mathrm{x} 40$ objective lens. Calibration is required, and in this study, the performance of the laser was calibrated against five 
standards: Spinel (Ro 0.393), YAG (Ro 0.929), GGG (Ro 1.7486), cubic zirconium (Ro 3.188) and silicon carbide (Ro 7.506).

Once calibrated, the laser light is bounced off the charcoal surface and its reflected value (Ro) recorded. Usually a number of measurements are made on one sample (50, or even 100), thus providing a range of Ro readings for one fragment of charcoal. If the charcoal concerned is very small (i.e. micro, rather than macro-sized), measurements in the 'one' sample may come from several small fragments. From the range of measurements for one sample, an average is calculated for that sample (Ro avge), and of course there are Ro min and Ro max measurements for that sample (as measured, but these may or may not represent actual minimum and maximum of the sample).

\section{Reflectance calibration curves}

A number of researchers have charred woods of various types under varying (controlled) conditions, measuring the absolute temperature of charring, over various timeframes, and then subsequently measuring the reflectance of these modern samples, in order to produce a calibration curve that relates the temperatures observed with the measured reflectance values. McParland et al. (2009b) produced their calibration curve by plotting the reflectance results (y-axis) against the known temperature of formation (x-axis) (Fig. 1). The formation temperatures of samples with unknown charring temperature may then obtained from the curve using the measured reflectance value (on the y axis), and reading the associated temperature from the $\mathrm{x}$-axis. In this study, the temperature calibration curve for oak created by McParland et al (2009) has been used since oak was the most common taxon in the cremation assemblages. Other curves for softer, harder, and/or more resinous woods read slightly differently. Temperature results of the archaeological material examined here were inferred using a 1,6,12 and $24 \mathrm{~h}$ calibration curve, i.e. the modern wood samples were charred and their temperatures measured - after 1 hour, 6 hours, 12, and 24 hours to create the calibration curve. The results are expressed as a range of temperatures e.g. a reflectance of $5 \%$ Ro would need to be charred at $900^{\circ} \mathrm{C}$ for one hour or $800^{\circ} \mathrm{C}$ for $24 \mathrm{~h}$ giving a range of $800-900^{\circ} \mathrm{C}$. A natural outworking of these observations suggests that quick charring to a particular temperature, (i.e. in one 
hour), will produce a higher reflectance value than slower charring (e.g. 24 hours) to the same temperature. Since cremation of a full body takes about one day, we might infer that slower charring might have been occurring, however, flame temperatures fluctuate over the cremation process, for example, upon original ignition of clothes, and starter materials (brush woods, or potentially oils), and again when body fats reach ignition temperature. As stated in the main text, much of the body is burnt in a few hours, and even when cremation is 'completed,' some body parts may not have been burnt.

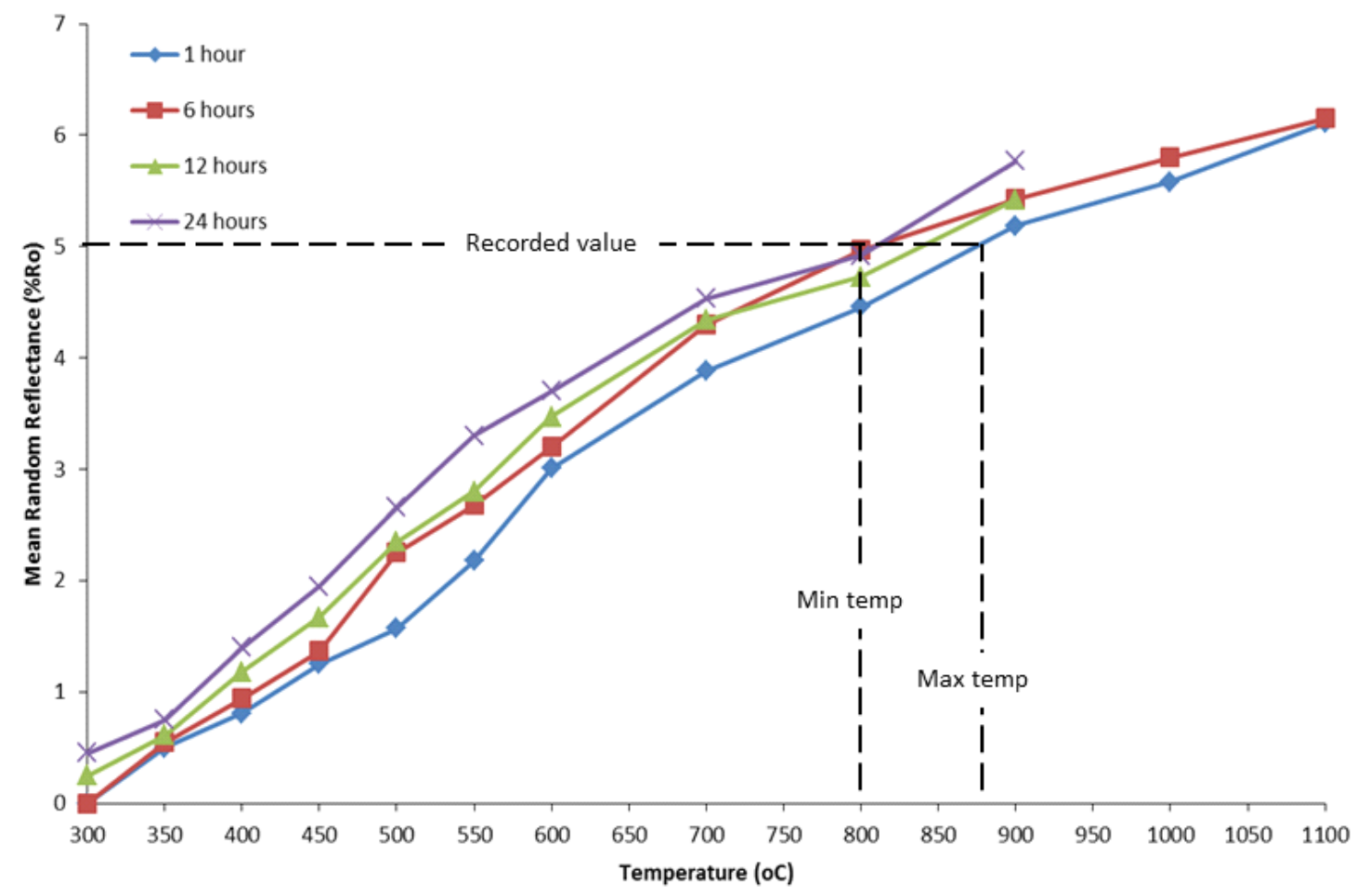

SUPPLEMENTARY FIGURE 1 Calibration graph of reflectance vs burn temperature (modified from McParland et al. 2009b) (Corresponds to figure 1 in main text).

The reflectance observed in charcoals is anisotropic in nature and therefore, the 
measurements taken will depend upon the position of the sample relative to the plane of polarisation of the laser light. Reflectance is reported either as maximum reflectance ( $\mathrm{R} \max )$ or random reflectance $(\% \mathrm{Ro})$. $\mathrm{R}$ max is measured by orientating the sample or polariser to provide the reflectance maximum (which takes time to carry out). \%Ro (mean random reflectance) simply takes a mean from the sample (from a number of measurements taken at random). Samples in this case have not been aligned to find the Ro max and therefore will often be lower. Mean random reflectance is reported throughout this study, in that the sample is not orientated before measuring. There is still a minimum random reflectance value and a maximum random reflectance value, however, these should not be confused with true maximum reflectance ( $\mathrm{R} \max$ ).

Generally, in coal samples, and in some other charcoal reflectance studies, calculating the average measurement is sufficient, however, given we are interested in the highest observable temperature as randomly measured (i.e. \%Ro max), we ultimately refer to the highest random measurement taken for each sample. By way of further explanation, in a study examining the phenomenon of 'vitrification' in archaeological charcoal, (McParland et al, 2010), the reflectance ranges were measured for a variety of charcoals obtained from different charring/burning modalities (see Supplementary figure 2). Reflectance of wildfire charcoals is also now carried out to test differences in wildfire regimes, e.g. crown fires vs ground fires, the former being much hotter than the latter, (Hudspith et al., 2015; Belcher and Hudspith, 2016). 


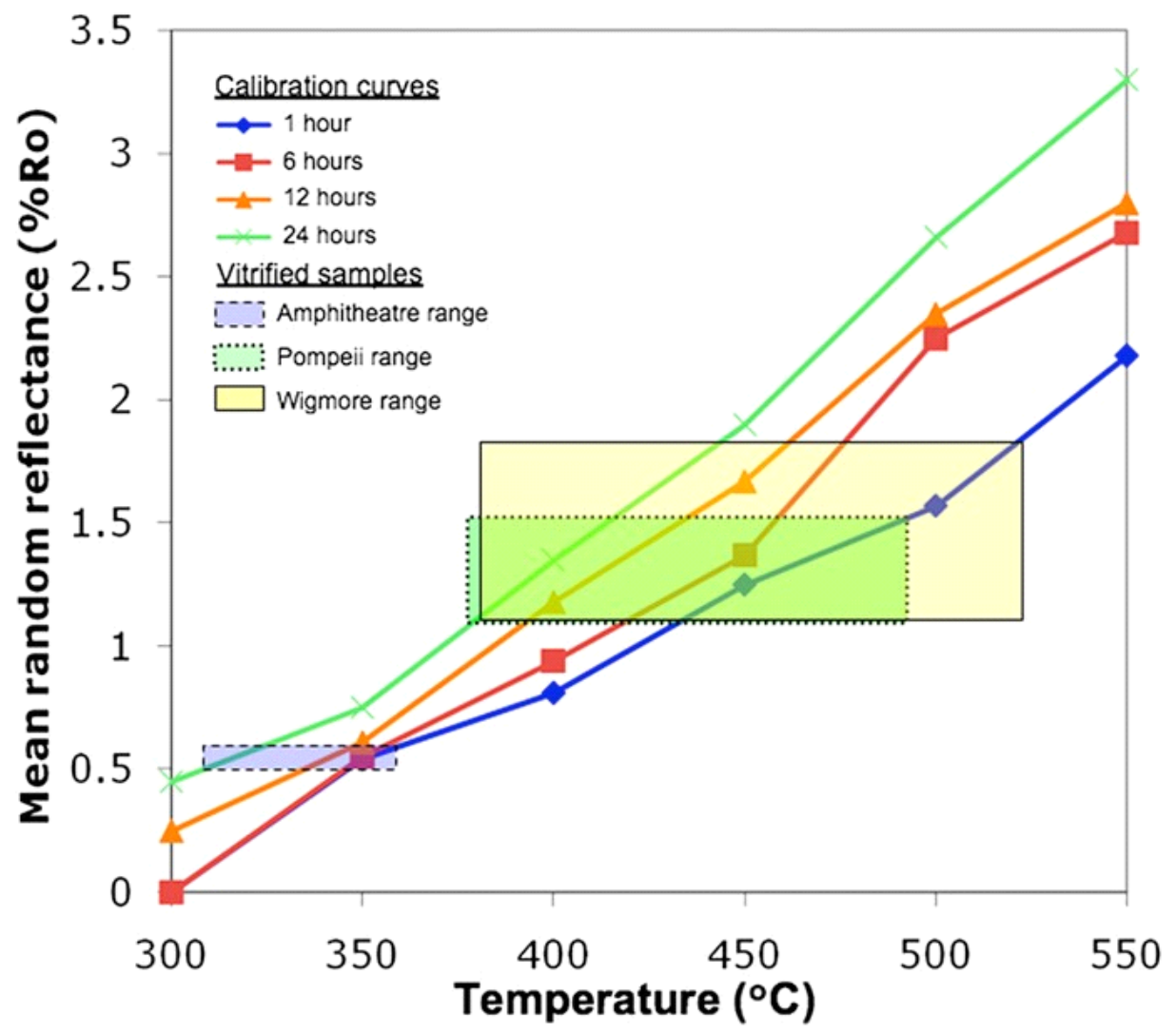

SUPPLEMENTARY FIGURE 2. From McParland et al. 2010. Range of mean random reflectance $(\% \mathrm{Ro})$ of the vitrified areas of the archaeological fragments from three archaeological sites: Pompeii, Wigmore and Chester amphitheatre, plotted against the calibration curves of temperature vs. reflectance (for experimentally charred oak) in order to show the range in temperature of formation of the vitrified charcoals. Laboratory calibration charring data from McParland et al. (2009a). 


\section{Fire, temperature and fuel behavior (supplementary material 2)}

A detailed understanding of how fire behaves may inform our understanding of fuel behavior during cremation, and its probable location after cremation is concluded. Much of our understanding about fire arises from studying wildfires, as well as forensic studies of modern fires where human are incinerated. This discussion draws on these sources, as well as limited works on ancient cremation.

The building of a cremation pyre will result in the provision of: the major fuel, timber logs possibly constructed in a pyramidal shape (with decreasing diameter); the secondary fuel (the body, especially the body fat); and the ignition fuels (which may be a range of products from kindling and shrubs to oils, we have little evidence for these from cremation sites). Bodies in modern and Roman cremations are normally placed on top of the pyre, in a shroud, or indeed in clothing (either of these provide more low ignition fuels). The major ignition fuels are placed around the base of, and potentially inside, (or in the case of oil, poured on to), the pyre, and ignition of these commences the burning process. The fire so started, must eventually transfer enough heat to the unburnt major fuel, the wood (Scott et al. 2014:302), and then also to the body; heat may be transferred by three different processes (Scott et al. 2014:303):

i) Convection: the transfer of heat by movement of a fluid (liquid or gas), including by actual flame contact. In a cremation, this is the natural movement of hot air and gaseous combustion products upwards, a process that will be further assisted by a draft. Convective heat is not visible to the naked eye.

ii) Radiation: transfer of heat in straight lines at the speed of light from hot particles of matter (solid, liquid, or gas) to cooler regions in the fuel layer, or its surroundings. In a modern open air cremation, this is felt from the visible flames, and will increase as the cremation proceeds. Uneven burning/spreading of flames will cause hot air turbulence, which may be significant and result in movement of burnt and partially burnt fuels. 
iii) Conduction: the transfer of heat through matter from a region of high temperature to a region of lower temperature. Again, conduction may add to turbulence, and thus fuel movement within the pyre.

As the ignition fuels burn, white vapours are emitted around $100{ }^{\circ} \mathrm{C}$ (if the fuel is not completely dry), this is water vapour. Following this stage as the temperature rises, organic hydrocarbons vaporize and are emitted (blue smoke). A similar pattern occurs with the wood. More detailed information is provided in Braadbaart et al. (2012:844), and Harrison (2013). Once flaming combustion is established on a fuel surface, it reaches an equilibrium condition where its temperature stabilizes no matter what the temperatures of the flames above may be (Dehann, 2008: 5). For wood the surface temperature of the horizontal fuel is of the order of $350-400{ }^{\circ} \mathrm{C}$. Radiant heat from flames above, and smouldering combustion in the surface are balanced against radiative and convective losses, and the vaporization of the organic volatiles. Wood fires produce a maximum flame temperature of $1027^{\circ} \mathrm{C}$ (Dehann, 2008: 4), however, flame temperature varies with height from the fuel surface. A steady flame reaches a maximum temperature just above the fuel surface $\left(800-900{ }^{\circ} \mathrm{C}\right)$ (Denhann, 2008:6). Fires are typically 'turbulent', with the surface of the burning fuel rising and falling, and the atmosphere ranging from reductive to occasionally oxidative. This living and changing nature of actual fire is very different to the conditions wrought by placing bone (or wood), in a laboratory oven at a specific temperature.

The best fuel in the body is the subcutaneous fat, which has an auto-ignition temperature of approximately $350^{\circ} \mathrm{C}$ (Dehann 2008:9). Body fat does not smoulder and will only burn as a flame, and it requires a rigid porous 'wick' to maintain the flame. This wick can be charred wood, clothing, or even bone. Body fat produces an average temperature of about $800{ }^{\circ} \mathrm{C}$, and turbulent flames (Dehann 2008:9). It contributes substantially to the burning process, evaporating body fluids, degrading, drying and finally burning skin, and muscle (which burns reluctantly). 
Modern house fires, where hot gases and pyrolysis products collect in a room, eventually reach a 'flashpoint' where the fire suddenly ignites these products, and temperatures can reach $1000{ }^{\circ} \mathrm{C}$, with post flashover temperatures as high as $1200{ }^{\circ} \mathrm{C}$ (Dehann 2008:11). Some Roman cremations were held 'inside' four walls (open to the sky), presumably to keep heat in, as substantial marble constructions have been excavated (e.g. the ustrina of Antininus Pius and that of Marcus Aurelius). In a prehistoric cremation, we have no knowledge of the positioning of regularly used pyre sites in this respect, but it cannot be discounted. 